\title{
Measuring corporate social responsibility towards employees
}

\author{
Anna Remišová, Zuzana Búciová ${ }^{* *}$
}

The paper presents a new methodology for measuring a corporate social responsibility (CSR) level based on the Integrative model of CSR. According to the model, which reflects European theoretical fundamentals of CSR, a company cannot be viewed as socially responsible if it does not accept at least basic responsibilities towards all its stakeholders. The main aim of the paper is to present the methodology of determining the CSR basis towards one selected stakeholder - employees, and to provide a set of indicators for measuring a CSR level towards them. The functionality of the indicators was tested in empirical research and proved to be applicable. The paper can be viewed as a guideline to define a CSR basis towards other stakeholders by analogy.

Der Artikel veranschaulicht eine neue Methodik zur Messung des gesellschaftlich sozialen Verantwortung (CSR)-Levels, basierend auf dem integrativen Modell von CSR. Nach dem Modell, welches die europäischtheoretische Grundlagen von CSR widerspiegelt, kann ein Unternehmen nicht als sozial-verantwortlich angesehen werden, wenn es nicht zumindest eine grundlegende Verantwortung gegenüber allen Interessengruppen akzeptiert. Das wichtigste Ziel dieses Artikels ist es, die Methodik zur Bestimmung der CSR-Grundlagen anhand einer ausgewählten Interessengruppe - den Mitarbeitern - zu präsentieren, und eine Reihe von Indikatoren zur Messung einer CSR-Grundlage bereitzustellen. Die Funktionalität dieser Indikatoren wurde in einer empirischen Forschung getestet und erwies sich als zutreffend. Der Artikel kann als Leitlinie angesehen werden um CSR gegenüber den anderen Interessengruppen in Analogie zu definieren.

Key words: corporate social responsibility (CSR), the integrative model of CSR, the CSR basis, stakeholder theory, business ethics.

\footnotetext{
Manuscript received: 19.06.11, accepted: 17.11 .11 (2 revisions)

** Prof. Dr. Anna Remišová, Professor of philosophy lecturing, Faculty of Management, Comenius University Bratislava and Faculty of Media, Paneuropean University. Main research areas: business ethics, ethics in media and analytical ethics. Corresponding address: anna.remisova@fm.uniba.sk

Mgr. Zuzana Búciová, PhD., Lecturer, Faculty of Management, Comenius University Bratislava. Main research areas: corporate social responsibility, business ethics and human resource management.
} 


\section{Introduction}

Although corporate social responsibility (CSR) is definitely not a new topic, it appears in the last few years that CSR is really coming into focus and spreading out over the business environment with new strength and urgency. In connection with the global economic crisis, which is often referred to as the "crisis of ethics," the necessity of taking corrective measures in the business environment becomes obvious (Búciová 2010a).

Corporate social responsibility, together with its sister concepts - corporate social responsiveness, corporate social performance, and corporate citizenship is a topic that has been present in management scholarship for more than sixty years. Scholarly literature on the subject dates back to at least the 1950s when Frank Abrams, a former executive with Standard Oil Company, New Jersey, introduced concerns about management's broader responsibilities in a complex world (Abrams 1951) and Howard Bowen published his key book Social Responsibilities of a Businessman (Bowen 1953), but according to Crane et al. (2008:3) commentators on business have written about the subject for considerably longer. At the beginning, it was discussed only by American authors and since the 1980s it has spread to Europe and other parts of the world. Even though it has been widely discussed for such a long period of time, researchers still do not share a common definition or a common set of principles. Despite a large and growing body of literature on CSR, consensus on its exact definition has not been reached yet (Lee 2008). De Baker's (2005) analysis of over 500 articles on CSR from the last thirty years led him to a conclusion that the field was vibrant and developing, but there was no evidence of further operationalisation of the general central concepts. CSR can be viewed as an umbrella term that overlaps with many conceptions of business-society relations (Matten/Crane 2005). What all those conceptions have in common is the core theme that organisations have responsibilities beyond profit maximisation (Garriga/Melé 2004). Some authors see CSR just as a philanthropic responsibility towards communities or the society. Others believe it is composed of ethical, economic and legal responsibility as well (Carroll 1979; Carroll 1999; Schwartz/Carroll 2003).

The main reason it is so complicated to agree on a single definition, is that understanding CSR is determined by different cultural, historical, political, legal and social conditions of individual countries as well as different subject fields of scholars discussing the issues. Crane and Matten state that, "CSR as a view of business responsibility in the society has been particularly strong as a concept in the USA, from where much of the authors, literature, and conceptualization have 
emerged. In Europe ${ }^{1}$, however, the concept of CSR has never been quite as influential" (Crane/Matten 2004:46). We can say the opposite about business ethics. After business ethics was established as an independent scientific discipline, European authors have intensely engaged in the issues. Búciová (2010a:34) thinks it can be assumed that European scholars did not take an interest in CSR during the first decades of its existence, as it originated from a different cultural, legal and historical background not close to European culture. Until the 1980s CSR addressed issues that did not reflect the European business situation. Raising the question of corporate ethical responsibilities caused European scholars to get interested in the issues and join the discussion on core principles of CSR. For European scholars, it is business ethics that matter, and thus it represents the bottom line of CSR. "In the USA where CSR has emerged, business ethics is viewed as an "alternative" or "complementary" topic to CSR. On the other hand, in Europe business ethics was broadly accepted by scholars and developed over years. It has also become an integral part of understanding CSR" (Búciová 2010a:35). CSR in Europe is seen as economic, legal and ethical responsibility towards all stakeholders, as the reevaluation of the role of corporations in society is more evident. The philanthropic responsibility is seen as a complementary issue. To be socially responsible, a corporation does not have to "pay a part of its profit back to society" but must make certain that profit is being achieved in a socially responsible way (Remišová/Búciová 2011).

The number of European corporations claiming social responsibility is increasing rapidly, and the majority of large leading corporations are members in various sustainability and CSR groups. However, in reality, it does not always mean they are really ethical or responsible to their stakeholders. Some of them simply take advantage of the non-existence of common CSR definition; others may be seriously confused about the extent of CSR activities. Therefore, we found it very important to create a new model for measuring CSR in accordance with European theoretical fundamentals of CSR that would also be applicable in the other parts of the world. The Integrative model of CSR (Remišová/Búciová 2011) has been developed with a unique methodology of assessing CSR. The model sets the CSR basis - the minimum requirements for a responsible behaviour of a corporation - complying with which is a must if an organisation wants to be viewed as socially responsible.

The main aim of this paper is to present the methodology of determining the CSR basis towards one selected stakeholder - employees, and to provide and verify a set of indicators for measuring a CSR level towards them. This paper

\footnotetext{
${ }^{1}$ When talking about Europe it is important to state what exactly is meant by the term Europe. We are aware of the fact that some authors distinguish between two ways of thinking. The first is an axiological and metaphysical way of thinking, which is typical for continental Europe. The other is pragmatic and empirical and is often referred to as the Anglo-American way of thinking. However, in this article we came to a similar conclusion as Crane and Matten (2004:27), that considering the long history of international relations within Europe, as well as increasing integration in recent years; ... one might reasonably argue that Europe as a whole represents a distinct world block that is different from that of North America.
} 
can be viewed as a guideline to define the CSR basis as well as indicators towards other stakeholders by analogy.

\section{Measuring corporate social responsibility on the basis of the Integrative Model of CSR}

The Integrative model of corporate social responsibility (Remišová/Búciová 2011) perceives a corporation as a "corporate citizen" who is obliged to meet its legal and ethical commitments and at the same time has some specific responsibility based on its status of an economic entity. It is based on an integrative approach to business ethics developed by P. Ulrich (1997; 2002; 2008) being also accepted by A. Remišová (2004; 2011) and her school of business ethics (e.g. Lašáková 2011, Búciová 2009; 2010b; 2011).

The model stands on four foundations: (1) generally accepted definition of CSR by Carroll according to which "the social responsibility of business encompasses the economic, legal, ethical, and discretionary expectations that society has of organisations at a given point in time" (Carroll, 1979, p. 500) with the first three components being an integral part of corporate activities. Whereas, the philanthropic responsibility is being understood as a desirable behaviour of corporations from the side of society; (2) accepting the idea that a corporation can act and acts as a subject of social responsibility, which means CSR cannot be understood merely as a sum of individual employee responsibilities; (3) the stakeholder theory (Freeman 1984; Jones et al. 2002) according to which an organisation should take responsibility for all relevant stakeholders in both its internal and external environment; (4) emphasising the ethical responsibility of an organisation as an integral part of all corporate activities.

The above mentioned foundations led to the following conclusions about CSR in the European business environment: (1) It is necessary to set the basis of corporate social responsibility, which would reflect fundamental requirements for a socially responsible behaviour of organisations in the area of economic, legal and ethical responsibilities. (2) Corporate social responsibility should be assessed based on the extent of institutionalization of economic, legal and ethical responsibilities into corporate activities. (3) It is only possible to talk about CSR in the case that an organisation consciously accepts responsibility towards all relevant stakeholders. (4) Corporate ethical responsibility should be viewed in a broader context - in the way it is presented by a great number of European authors. Organisations should accept the responsibility and commit themselves to follow these moral rules and the essential condition of business ethics, "Do not harm others!"

One of the greatest challenges of the model was defining the CSR basis, which should reflect the elementary requirements for responsible business behaviour. As it was already mentioned, we had come to the conclusion that CSR must inevitably include ethical, economic and legal responsibilities, and should be 
specified to each stakeholder separately. In general, it was set as follows (Remišová/Búciová 2011):

The basis of legal responsibility results from compliance with the law in force governing the relations of an organisation to a particular stakeholder. A corporation fails to comply with the basis of the legal responsibility in the case that a relevant authority has taken a final decision and definitely found an organisation guilty of a violation of law in at least one case, in relation to one or more of its stakeholders in the period concerned.

The basis of economic responsibility is specified for each stakeholder individually, and reflects their minimum requirements for economic responsibility. A corporation fails to comply with the basis of economic responsibility in the case that it has broken whatever requirements specified within the period concerned.

The basis of ethical responsibility represents the specification of the ethical principle "Do not harm others!" in relation to individual stakeholders. Compliance with the basis of ethical responsibility shall be demonstrated by the institutionalization of specific ethical processes and procedures. The basis of ethical responsibility is met as long as there is demonstrably both a strategic concept and a functioning system of the execution of this concept, in every area specified, for each individual stakeholder.

A CSR measurement should be carried out in two separate steps. Compliance with the CSR basis should be evaluated first, followed by an evaluation of activities beyond the CSR basis. A corporation scores no points for compliance with CSR as the basis represents the minimum of CSR. However, in case a corporation has failed to meet a requirement of the CSR basis, it is awarded a minus point (one point for each requirement that has not been met). As long as a corporation achieves a negative value (this happens if an organisation has failed to meet even one criterion of the CSR basis), it gets below the line of CSR and thus cannot be regarded as socially responsible in relation to a given stakeholder. In such a case, the organisation cannot be given any points for additional activities it has been carrying out in favour of a given group of stakeholders beyond the CSR basis. The model does not accept the possibility of "compensation" for the criteria of the CSR basis that have not been met by other activities beyond the core principles of economic, legal and ethical responsibilities.

Corporations that comply with the CSR basis proceed to the second part of a CSR measurement - evaluation of other activities an organisation has been performing towards a given stakeholder. Here they are assessed against a set of specific indicators for which they receive positive points. The final total score an organisation has achieved determines the range of socially responsible activities of a corporation in relation to a given stakeholder. The content and quality of 
those activities are described in a final evaluation report on corporate social responsibility of a particular company.

\section{Defining CSR in relation to employees}

In her dissertation, Búciová (2010b) has carried out theoretical research to concretize the Integrative model of CSR towards one selected stakeholder employees, to prove its functionality and validity. Based on analysis of the most frequently used guidelines and standards in the area of CSR, seven main areas of CSR towards employees were identified: (1) compensation issues, (2) health and safety, (3) work conditions and corporate social politics, (4) labour relations and collective bargaining, (5) work dignity and protection against discrimination, (6) individual work relations and internal communication, (7) enforcing employee rights. In these seven areas, indicators for measuring CSR were set in two categories - indicators identifying particular requirements arising from the CSR basis and indicators for evaluating corporate activities beyond the scope of minimum economic, legal and ethical requirements.

The CSR basis is achievable for all large organisations regardless of the volume of their financial resources. In fact, the CSR basis does not monitor the amount of money invested in employees by an organisation, but the way the processes to create an appropriate work environment for its employees are set up. Additionally, it monitors the fact, whether or not the relationship with its employees is based on mutual trust, respect and responsibility.

Meeting the basis of legal responsibility towards employees means complying with the labour legislation of a particular country. The indicators were set based on the European Social Charter requirements. In assessing corporate legal responsibility for a group of employees, compliance with the country's national employment law is being assessed. (Table 1). If the final decision was taken by the relevant authority that the corporation violated law in force in at least one case in the period concerned (usually a year), the basis of legal responsibility is not met.

An organisation earns one minus point for every area where infringements of legal provisions have been found. The model of a CSR assessment uses scoring methods to demonstrate the extent of corporate social responsibility (or irresponsibility). Therefore, an organisation scores (-1) point for each area where it has breached the law and not for each individual case of an infringement of the law (the actual number of cases is stated in the final evaluation report on the state of corporate social responsibility). The number of minus points evinces whether there have been problems with infringement of the law just in one specific area, where appropriate changes should be made, or there have been widespread infringements of the law in several areas. 
Table 1: The basis of legal responsibility to employees

\begin{tabular}{|l|l|}
\hline Compensation issues & Legal responsibility indicators \\
\hline Health and safety & 1. Right to fair remuneration for the work performed. \\
\hline 2. Provision of occupational safety and health (OSH). \\
3. Liability for damages caused to an employee by a work \\
accident or occupational disease.
\end{tabular}

The basis of economic responsibility towards employees was set in terms of paying employees on time and paying all taxes and other legally required payments to social and health insurance funds, etc. The assessment is based on the wage and social legislation applicable in a specific country and it assesses a punctual payment of wages and liability to pay contributions for employees to insurance companies (Table 2).

An organisation fails to comply with the basis of corporate economic responsibility if there has been a violation of any conditions stated within the period concerned. In case an organisation does not meet any of the conditions given, it gets one minus point (-1 point) for the violation. For non-compliance with the minimum of corporate economic responsibility towards employees, an 
organisation may be given two minus points in total. The number of individual cases of infringement in the given areas is specified in the final corporate evaluation report.

Table 2: The basis of economic responsibility to employees

\begin{tabular}{|l|l|}
\hline & Economic responsibility indicators \\
\hline Compensation issues & $\begin{array}{l}\text { Punctual payment of salaries for the work performed. } \\
\text { During the reference period, the organisation has always } \\
\text { paid salaries to its employes on the date agreed. }\end{array}$ \\
& $\begin{array}{l}\text { Contributions to the Social Insurance Company, Health } \\
\text { Insurance Company and individual funds. } \\
\text { All mandatory contributions have been paid on time, at the } \\
\text { right amount and in compliance with applicable law. }\end{array}$ \\
\hline
\end{tabular}

The basis of ethical responsibility represents specification of the ethical minimum in the relationship between an employer and an employee. It is based on the Good Corporation Standard (2007) of which establishment of a minimum level of corporate social responsibility specified. Sixteen different indicators were identified within the seven basic areas of CSR to employees (Table 3). In order to meet each of the indicators, a corporation must prove the existence of a strategic concept as well as show policy to implement the strategy in everyday life.

An organisation fails to comply with the basis of ethical responsibility if there is no defined strategic concept or a functional system for its implementation in any of the sixteen mentioned areas. For every area in which there is no defined strategic concept as well as a functioning system for implementation (or an organisation fails to demonstrate the existence of such a system), an organisation is given one minus point.

Table 3: The basis of ethical responsibility to employees

\begin{tabular}{|c|c|}
\hline & Ethical responsibility indicators \\
\hline Compensation issues & $\begin{array}{l}\text { 1. Employees know when and how their remuneration is being } \\
\text { determined. } \\
\text { 2. In determining remuneration, an organisation takes into } \\
\text { consideration local living costs and level of salaries in a } \\
\text { positive sense. }\end{array}$ \\
\hline Health and safety & $\begin{array}{l}\text { 3. An organisation has developed the concept of occupational } \\
\text { health and safety as well as relevant policies and procedures } \\
\text { of its implementation and monitoring. } \\
\text { 4. An organisation has developed the concept and effective } \\
\text { system of regular vocational training aimed at implementation } \\
\text { of the principles and procedures concerning occupational } \\
\text { safety and health for all the employees. }\end{array}$ \\
\hline
\end{tabular}




\begin{tabular}{|c|c|}
\hline $\begin{array}{l}\text { Work conditions and } \\
\text { corporate social politics }\end{array}$ & $\begin{array}{l}\text { 5. An organisation has clearly defined work conditions for all } \\
\text { employees. } \\
\text { 6. An organisation has clearly defined disciplinary procedures } \\
\text { which are equitably applied to all. } \\
\text { 7. An organisation has developed policies and procedures to } \\
\text { provide its employees with appropriate training necessary for } \\
\text { their work performance. } \\
\text { 8. At least once a year the work performance of employees is } \\
\text { being assessed within the organisation, taking into } \\
\text { consideration their qualifications and career prospects. } \\
\text { 9. An organisation has established policies and procedures that } \\
\text { guarantee the employment of children and youths is in } \\
\text { compliance with internationally accepted standards. }\end{array}$ \\
\hline Collective bargaining & $\begin{array}{l}\text { 10. An organisation respects freedom of assembly and association } \\
\text { of employees. }\end{array}$ \\
\hline $\begin{array}{l}\text { Work dignity and } \\
\text { protection against } \\
\text { discrimination }\end{array}$ & $\begin{array}{l}\text { 11. An organisation has defined a strategic concept of equal } \\
\text { opportunity which is aimed at hiring, promoting and } \\
\text { remunerating employees just on the principle of merit. } \\
\text { Compliance with the strategic concept is monitored on a } \\
\text { regular basis. } \\
\text { 12. The principle of treating all the employees with respect and } \\
\text { not to tolerate any form of harassment is applied within the } \\
\text { organisation. }\end{array}$ \\
\hline $\begin{array}{l}\text { Individual work relations } \\
\text { and internal } \\
\text { communication }\end{array}$ & $\begin{array}{l}\text { 13. An organisation has developed a communication system with } \\
\text { employees and an employee counselling system which are } \\
\text { functioning. } \\
\text { 14. An organisation has implemented the system ensuring the } \\
\text { privacy of employees is respected. }\end{array}$ \\
\hline $\begin{array}{l}\text { Enforcing employee } \\
\text { rights }\end{array}$ & $\begin{array}{l}\text { 15. An organisation has implemented effective complaint } \\
\text { resolution procedures. } \\
\text { 16. An organisation has implemented an effective system to } \\
\text { monitor compliance with the applicable norms and standards } \\
\text { concerning work and employment. }\end{array}$ \\
\hline
\end{tabular}

The second part of the assessment following the measurement of the CSR basis is focused on other corporate activities in relation to a particular stakeholder. An organisation is given positive points for the optional activities and commitments it has adopted on a voluntary basis. The final total score an organisation has achieved determines the range of its socially responsible activities in relation to a given stakeholder.

Here it is important to underline that even if an organisation gains no positive points it is considered socially responsible if it complies with the CSR basis (in this case the score equals 0 ). A lot of corporations do a lot more in relation to the individual stakeholders, and therefore, it is necessary to also assess all the activities beyond the scope of the CSR basis which make a particular organisation unique and enhance its social responsibility to a particular 
stakeholder. Tables 4-6 depict indicators of the CSR enhancement towards employees an organisation can be given positive points for.

Table 4: Enhancement of corporate social responsibility to employees - part 1

\begin{tabular}{|c|c|c|}
\hline & CSR enhancement indicators & Points/Score \\
\hline $\begin{array}{l}\text { Compensation } \\
\text { issues }\end{array}$ & $\begin{array}{l}\text { - Remunerations and bonuses dependent on an } \\
\text { employee's performance are forming parts of the } \\
\text { corporate remuneration system. } \\
\text { - An organisation provides employees with the } \\
\text { following benefits (fringe benefits) on a standard basis: } \\
\text { - Life insurance contribution (or the 3rd retirement } \\
\text { pillar contribution), } \\
\text { - Healthcare, } \\
\text { - Disability/invalidity contributions, } \\
\text { - Maternity/parental leave, contribution or time off } \\
\text { work beyond the scope of the law when taking care } \\
\text { of a child, } \\
\text { - Fidelity bonuses for the years worked (regular } \\
\text { contributions to food for the retired, meetings, } \\
\text { training, etc.), } \\
\text { - Possibility to acquire employee stock options, } \\
\text { - Other regular activities beyond the scope of the law } \\
\text { (e.g. food beyond the scope of the law, maximum } 2 \\
\text { activities). }\end{array}$ & $\begin{array}{l}1 \text { point } \\
1 \text { point } \\
1 \text { point } \\
1 \text { point } \\
1 \text { point } \\
1 \text { point }\end{array}$ \\
\hline $\begin{array}{l}\text { Health and } \\
\text { safety }\end{array}$ & $\begin{array}{l}\text { An organisation shall provide employees with: } \\
\text { - } \quad \text { Training and education in OSH beyond the scope of } \\
\text { statutory requirements, } \\
\text { - } \quad \text { Training and education concerning serious illnesses } \\
\text { and/or health counselling, } \\
\text { - } \quad \text { Health prevention and risk of serious diseases } \\
\text { programs, } \\
\text { - } \quad \text { Illnesses treatment support, } \\
\text { - Other activities in occupational health care (maximum } \\
2 \text { activities). }\end{array}$ & $\begin{array}{l}1 \text { point } \\
1 \text { point } \\
1 \text { point } \\
1 \text { point } \\
1 \text { point each }\end{array}$ \\
\hline
\end{tabular}


Table 5: Enhancement of corporate social responsibility to employees - part 2

\begin{tabular}{|c|c|c|}
\hline & CSR enhancement indicators & Points/Score \\
\hline $\begin{array}{c}\text { Work } \\
\text { conditions } \\
\text { and } \\
\text { corporate } \\
\text { social } \\
\text { politics }\end{array}$ & 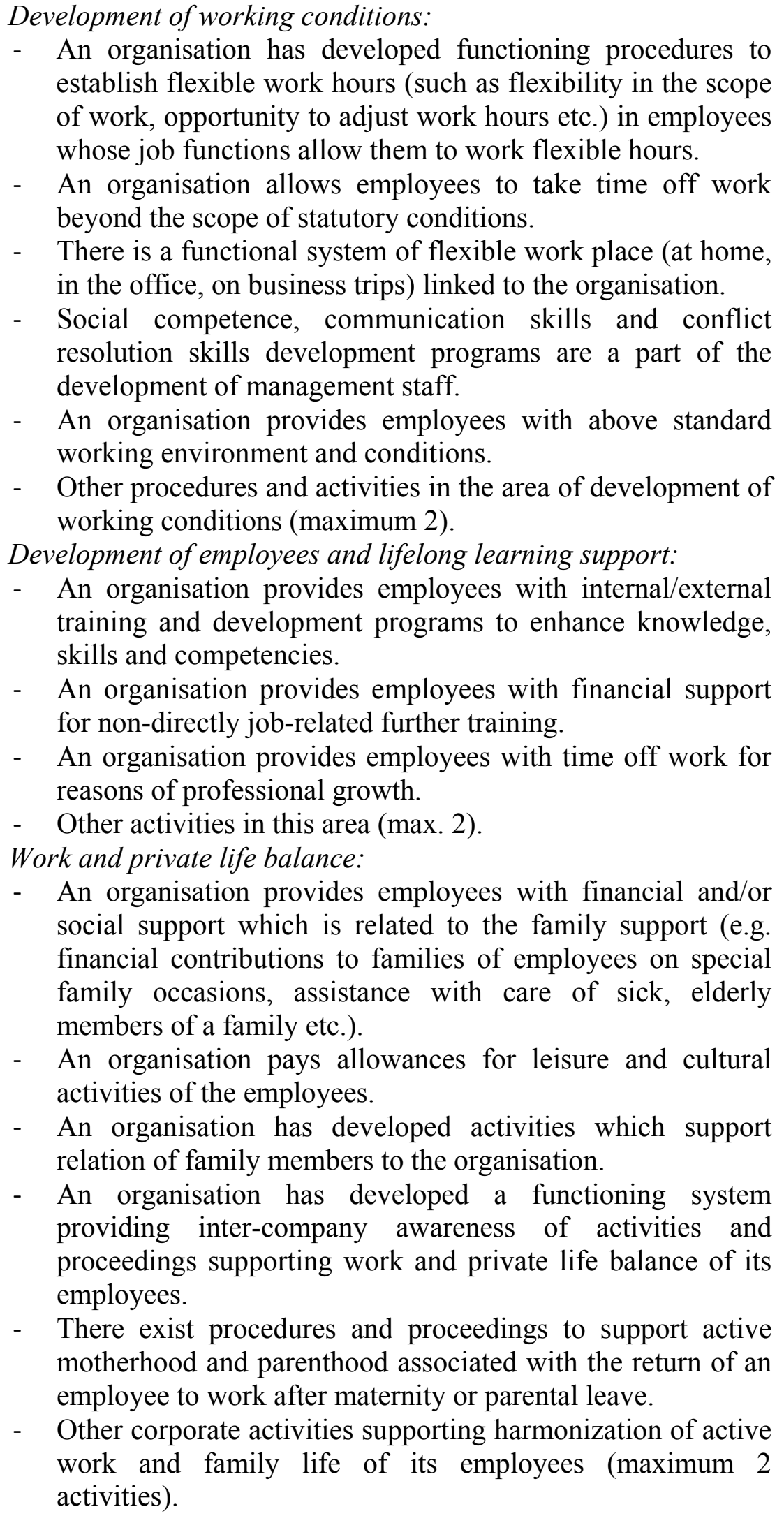 & $\begin{array}{l}1 \text { point } \\
1 \text { point } \\
1 \text { point } \\
1 \text { point } \\
1 \text { point } \\
1 \text { point each }\end{array}$ \\
\hline
\end{tabular}




\begin{tabular}{|l|l|r|}
\hline Services for leaving employees and retirees: & \\
An organisation provides future pensioners or leaving employees & \\
with: & 1 point \\
$-\quad$ Retraining courses for leaving employees, & 1 point \\
$-\quad$ Severance payment exceeding statutory requirements, & 1 point \\
$-\quad$ Assistance with searching for a new job, & 1 point \\
$-\quad$ Counselling services in case of change or job termination, & \\
$-\quad$ Other activities concerning services for leaving employees & 1 point each \\
\hline
\end{tabular}

Table 6: Enhancement of corporate social responsibility to employees - part 3

\begin{tabular}{|c|c|c|}
\hline & CSR enhancement indicators & Points/Score \\
\hline $\begin{array}{l}\text { Collective } \\
\text { bargaining }\end{array}$ & $\begin{array}{l}\text { Fringe benefits above the scope of a higher collective } \\
\text { agreement or other binding document have been } \\
\text { adopted by collective bargaining. }\end{array}$ & 1 point \\
\hline $\begin{array}{l}\text { Work dignity and } \\
\text { protection against } \\
\text { discrimination }\end{array}$ & \multirow{3}{*}{$\begin{array}{l}\text { Establishment of ethical standards and integration of } \\
\text { ethics to everyday corporate activities: } \\
\text { - } \quad \text { An organisation has developed a code of conduct } \\
\text { or a similar document establishing ethical conduct } \\
\text { requirements for employees and it is put into } \\
\text { practice. } \\
\text { - There is a functioning tool to monitor ethical } \\
\text { behaviour of employees which applies to all } \\
\text { corporate employees equally. } \\
\text { There exist functioning tools to report non-ethical } \\
\text { conduct without imposing any possible } \\
\text { threats/sanctions against the reporter and an } \\
\text { organisation demonstrably resolves ethical } \\
\text { problems reported. } \\
\text { An organisation provides employees with ethical } \\
\text { training. } \\
\text { An organisation provides employees with ethical } \\
\text { counselling and assistance with solving ethical } \\
\text { issues they experience at work (avoidance of } \\
\text { potential conflicts of interests, resolving of ethical } \\
\text { dilemmas, help with ethical decision-making etc.). } \\
\text { Other activities to support implementation of } \\
\text { ethics to corporate activities (maximum } 2 \\
\text { activities). }\end{array}$} & \\
\hline $\begin{array}{l}\text { Individual work } \\
\text { relations and } \\
\text { internal } \\
\text { communication }\end{array}$ & & 1 point \\
\hline $\begin{array}{l}\text { Enforcing } \\
\text { employee rights }\end{array}$ & & 1 point each \\
\hline Other activities & $\begin{array}{l}\text { Unique corporate activities which cannot be included } \\
\text { in any of the previous categories (maximum } 2 \\
\text { activities). }\end{array}$ & 1 point each \\
\hline
\end{tabular}

An important question to be raised is who can be expected to do this measurement of CSR to ensure objectivity. We suppose the model can be used for an organization's self-evaluation and should be carried out by an independent external auditor for ethics, a member of an ethical council or an 
independent commission in which all stakeholders would be represented. Establishing the measurement is a complex and time-consuming process. Its goal should be to find out a real state of the CSR development and to remove mistakes and improve it. We suppose that once an organisation undertakes such an exacting process, it intends to gain a real picture of its activities. We think an organisation that is not willing to obtain objective results is unlikely to start such a measurement. However, in case the Integrative Model of CSR would spread, it would be necessary to work out an approach to creating a commission for measuring CSR.

\section{Testing the model's functionality}

Functionality of the model for measuring the CSR level to employees was tested in empirical research on a large multi-national company operating in Slovakia (Búciová, 2010b). The chosen organisation is particular about CSR. It is a member of Business Leaders Forum in Slovakia and has already won various awards for a long-term systematic approach to CSR, ethical conduct, transparency, combating corruption, responsibilities to employees, workplace health, etc. In 2010, more than 2300 people were employed by the company in Slovakia.

The reason for choosing this particular organisation was to find out whether the presented indicators can meet the needs of a leading company in CSR. On the example of the CSR leader, we wanted to verify or disprove that all possible CSR activities can be classified using the Integrative model of CSR. We also wanted to know the company's reaction to setting the CSR basis.

\section{Method}

Before the assessment started, the persons participating in it (human resources manager and a compensation specialist) had been acquainted with the Integrative model of CSR, its fundamentals and logic as well as with the methodology of measuring CSR towards employees. As one of the research goals was to get feedback on the model, it was necessary to familiarize the participants with the method prior to the assessment. To assess the company a qualitative research was conducted in three consequent steps: (1) obtaining primary information about the state of CSR to employees by a questionnaire, (2) verification of assertions mentioned in the questionnaire, and (3) finishing the results and getting feedback on the model as well as the assessment process.

First, primary information about whether the organisation complies with the individual indicators was obtained by a questionnaire. It consisted of four parts three of them were focused on the three components of the CSR basis (economic, legal and ethical) and the last one dealt with activities indicating a CSR enhancement. The goal of this step was to get acquainted with the scope of CSR to employees and to grasp relevant internal documents and procedures that 
can prove its institutionalisation. After completing the questionnaire by the participating persons, the organisation made accessible the documentation concerning the issues stated in the questionnaire. Each part of the questionnaire was filled in by the most relevant person responsible for the particular issues in the company, if some other department of the company was in command of the issues (e.g., Health \& Safety), it was contacted by the Human Resources department to provide information as well as documentation on the issues.

In the second step, all documentation was analysed to verify or disprove the claims about CSR processes and activities stated in the questionnaires. After the verification process, a preliminary report on the state of CSR to employees was compiled.

In the third step, a semi-structured interview was conducted with the human resources manager as well as other participating people. The interview had two goals - to model the real situation in the company by discussing selected indicators or contradictory responses given in the questionnaire and, after completing the whole assessment process, to get feedback on the functionality of the tested model. The participants were asked to provide feedback on the model itself, the assessment method, the scope and formulation of the indicators, and the justifiability of the CSR basis.

\section{Results}

The CSR basis. The basis of legal responsibility was met in the year concerned. No final decision was taken by a relevant authority that the company violated law in force in any of the areas mentioned.

Employees were paid on time, and all mandatory payments to social and health insurance funds were paid on time and in the correct amounts. In one case, the company erred in its payment to social insurance funds, but this error was not considered as a breach of the basis of economic responsibility. It was a case of an employee who retired and therefore, should pay a reduced amount of money to social insurance funds. The company's contractor responsible for processing payrolls made a mistake in notifying the social insurance company (as the contractor used the usual form of the notice and had not examined whether there was a change in the form of notice), so charges were made in an incorrect amount (higher than necessary). The assessed company has pointed out the contractor's error and corrected it immediately. All liabilities to the employee were promptly met. As the company managed to find the error through internal control mechanisms and correct it in a short time, the employee was not aggrieved in the relation to statutory duties. Since the company has not failed in carrying out its mandatory economic duties, we do not consider this case a breach of the basis of economic responsibility.

For every area stated in the basis of ethical responsibility, the company has proved to have a defined strategy as well as a functioning system for its 
implementation. There existed thorough processes covering all areas mentioned in the indicators, all of them well-functioning, with appropriate control systems and sanctions.

The assessed company has complied with all three components of the CSR basis to employees - it did not receive any minus points. According to the model, it can be viewed as socially responsible to this stakeholder. Therefore, a second part of the CSR assessment followed - evaluation of activities exceeding the CSR basis.

Enhancing CSR. The company has scored 42 points (from a maximum of 50) for activities that exceed the CSR basis. The 42 points show a huge commitment in the company's CSR activities towards employees. Based on the report on CSR prepared for the company, it can be concluded that these activities are also rich in content and quality. The tested indicators covered all activities of the company; nine times it has used the opportunity to add other specific activities that were not included in the indicators offered. These activities are listed in Table 7.

\section{Table 7: Specific CSR activities of the assessed company}

\begin{tabular}{|c|c|}
\hline $\begin{array}{l}\text { Other CSR enhancement activities } \\
\text { to employees }\end{array}$ & Points/Score \\
\hline $\begin{array}{l}\text { Compensation issues } \\
\text { Other regular activities beyond the scope of the law (maximum } 2 \text { activities): } \\
\text { - Social allowance. The company provides employees with an optional } \\
\text { social allowance of approximately } 1600 € \text { per annum. Half of the amount } \\
\text { can be used for sport, relaxation, recreation, culture, education, health } \\
\text { services or other purposes (e.g. to cover transportation costs). After } \\
\text { providing evidence, these costs are reimbursed by the company. } \\
\text { Employees receive the other half of the amount as a monthly allowance } \\
\text { to cover other social needs not included in the system. } \\
\text { - Holiday allowance. The company provides its employees with a holiday } \\
\text { allowance that is paid in May every year. The allowance should serve } \\
\text { primarily to cover employee's holiday expenses but can be used to pay } \\
\text { for the employee's family members, as well. }\end{array}$ & 1 point \\
\hline $\begin{array}{l}\text { Health and safety } \\
\text { Other activities in occupational health care (maximum } 2 \text { activities): } \\
\text { - Comprehensive risk assessment program. The company has established a } \\
\text { comprehensive risk assessment programme, which is aimed to minimize } \\
\text { health, ergonomics, technical, technological and environmental hazards } \\
\text { in the workplace. It assesses possible risks arising from work on a regular } \\
\text { basis and takes all necessary measures to improve the working } \\
\text { conditions. } \\
\text { - Supplementary pension insurance. The employer pays insurance } \\
\text { premiums for supplementary pension for an employee during the period } \\
\text { of his incapability to work after it exceeds } 30 \text { consecutive days. }\end{array}$ & 1 point \\
\hline
\end{tabular}




\begin{tabular}{|c|c|}
\hline $\begin{array}{l}\text { Work conditions and corporate social politics } \\
\text { Other procedures and activities in the area of development of working } \\
\text { conditions (maximum 2): } \\
\text { - Shorter working-time. The company applies shorter weekly working-time } \\
\text { for all employees than the maximum weekly working time set by the } \\
\text { legislation, without reflecting this situation in any cuts in wages or } \\
\text { salaries. } \\
\text { Other corporate activities supporting harmonization of active work and } \\
\text { family life of its employees (maximum } 2 \text { activities): } \\
\text { - Interest-free loans for housing. Loans can be used for building or buying } \\
\text { a house or flat or for reconstruction works. } \\
\text { - Emergency financial help. Employees may apply for financial help in } \\
\text { emergency situations. } \\
\text { Other activities concerning services for leaving employees and retirees } \\
\text { (maximum } 2 \text { activities): } \\
\text { - Supporting retired employees. The company provides meal allowances } \\
\text { for retired employees and financially supports Senior Centre providing } \\
\text { cultural, educational and sport activities. }\end{array}$ & $\begin{array}{l}1 \text { point } \\
1 \text { point }\end{array}$ \\
\hline $\begin{array}{l}\text { Work dignity and protection against discrimination individual work } \\
\text { relations and internal communication enforcing employee rights } \\
\text { Other activities to support implementation of ethics to corporate activities } \\
\text { (maximum } 2 \text { activities): } \\
\text { - Supporting ethical thinking. Important ethical topics are regularly } \\
\text { presented in the company newspaper in full-page articles as well as in the } \\
\text { form of open-ended ethical dilemmas. Employees try to solve the } \\
\text { dilemmas and compete for the best possible alternative. The best } \\
\text { solutions are published in the next issues to explain the problems in depth } \\
\text { and to familiarize employees with ethical work practices. }\end{array}$ & 1 point \\
\hline
\end{tabular}

Overall feedback. A very important part of the research was to obtain feedback on the functionality of the model by verification from people who participated in the research. During the assessment, there were no circumstances, which would call into question the functionality of the tested model. According to the feedback, the model as well as the assessment method proved to be applicable. No serious problems in assessing the CSR level to employees were identified. The participants stated that thanks to the assessment they now have a better understanding of CSR. Prior to assessment, they did not realise the complexity of CSR to employees or the high number of activities that could be seen as part of it. They admitted that even though their company had ethical values and encouraged responsible and ethical behaviour and processes, it had not been until the assessment that they had seen them as a complex. The model gave them an opportunity to paint a complete picture about socially responsible activities to employees, which could help the company increase targeted CSR to employees, in the future.

The participants gladly accepted the idea of setting the CSR basis to define responsible behaviour. They agreed that it was necessary to establish stricter criteria for assessing whether an organisation is socially responsible or not. The 
participants considered establishing the CSR basis to be an important step in measuring CSR, as it can potentially prevent "irresponsible" companies from "abusing" the concept for marketing purposes only. The CSR basis was evaluated as achievable for any large organisation since achievement does not require additional financial resources.

\section{Conclusion}

Albert Einstein is often quoted as having said, "Not everything that can be counted counts and not everything that counts can be counted." His words apply to CSR more than it seems at first sight. There are numbers of corporations counting everything possible to show their positive impact on the environment, customers, communities or society as a whole to secure an image of caring organisation. On the other hand, there are not so many making a real difference. They are trying hard, pressing for ethical values, striving to remain fair and responsible in their everyday activities and decisions. The majority of CSR reporting or assessment frameworks that are used worldwide cannot quantify such contributions and so, paradoxically, they are often overshadowed in CSR by less responsible corporations.

It is quite usual that organisations known for their CSR activities have problems abiding the law, or are exploiting at least one of their stakeholders. This fact underlines the necessity to introduce stricter rules that companies should meet if they want to qualify as socially responsible. It is extremely important to avoid a superficial perception of CSR by clearly defining at least a minimum standard for socially responsible behavior of an organization so that CSR can gain a clear meaning and importance.

The Integrative model of CSR makes it possible to measure CSR in a completely new way that respects the European theoretical fundamentals of CSR. According to the model, it is impossible to limit CSR only to philanthropic responsibility. To be socially responsible means to act economically, legally and ethically responsible in day-to-day business towards all stakeholders. The model makes it possible to specify the content of socially responsible practices towards each stakeholder separately. Specifying the responsibilities helps in intentional achievement and development CSR as it enables corporations to grasp the issue in a more complex and systematic way. Using an example of one selected stakeholder we demonstrated how the CSR indicators should be set. To specify CSR for other stakeholders, one can proceed by analogy.

During our research, we have received a favourable response to the presented ideas of assessing CSR. We believe that corporations that are serious about CSR, would appreciate a standard that would separate responsible organisations from those trading on the lack of clarity on the issue. We hope that the Integrative model of CSR can serve as a tool to distinguish corporate social responsibility from philanthropic activities taken out of business context. 


\section{References}

Abrams, F. (1951): Managment's Responsibilities in a Complex World, in: Harvard Business Review, 29, 29-34.

Bajzíková, L./Piškanin, A./Lašáková, A. (2010): Manažment v globálnom prostredí. Bratislava: Fakulta managementu Univerzity Komenského.

Búciová, Z. (2009): O zmenách v chápaní spoločenskej zodpovednosti podnikov, in: Kdo je aktérem společenské odpovědnosti firem?, Olomouc: MVSO.

Búciová, Z. (2010a): Defining the Basis of Corporate Social Responsibility in the European Business Environment, in: Journal of Human Resource Management, 1-2, 31-41.

Búciová, Z. (2010b): Measuring Corporate Social Responsibility Level on the Basis of the Integrative Model. [Dissertation]. Bratislava: Comenius University in Bratislava.

Búciová, Z. (2011): Integrujúci model spoločenskej zodpovednosti podnikov, in: Společenská odpovědnost firem - transfer vědeckých poznatku do praxe, Olomouc: MVSO.

Bowen, H. (1953): Social Responsibilities of the Businessman. New York: Harper \& Row.

Carroll, A. B. (1979): A Three-Dimensional Conceptual Model of Corporate Performance, in: Academy of Management Review, 4, 4, 497-505.

Carroll, A. B. (1999): Corporate Social Responsibility: Evolution of a Definitional Construct, in: Business and Society, 38, 3, 268-295.

Carroll, A. B./Shabana, K. M. (2010): The Business Case for Corporate Social Responsibility: A Review of Concepts, Research and Practice, in: International Journal of Management Reviews, 12, 85-105.

Crane, A./Matten, D. (2004): Business Ethics. Oxford University Press: New York.

Crane, A./McWilliams, A./Matten, D./Moon, J./Siegel, D. (2008): The Oxford Handbook of Corporate Social Responsibility. Oxford University Press: New York.

Council of Europe: The European Social Charter. [online] 2011 [cit. 20.7.2011] Retrived from http://www.coe.int/t/dghl/monitoring/socialcharter/Presentation/AboutCharter_en.asp

Freeman, E. (1984): Strategic Management: A Stakeholder Approach. Marshfield : Pittman.

Garriga, E./Melé, D. (2004): Corporate Social Responsibility Theories: Mapping the Territory, in: Journal of Business Ethics, 53, 1-2, 51-71.

Jones, T.M./Wicks, A.C./Freeman, R.E. (2002): Stakeholder Theory : The State of the Art, in: The Blackwell Guide to Business Ethics, London : Blackwell Publishers.

Lašáková, A. (2011). Etické princípy v manažmente l'udských zdrojov: vymedzenie a praktická aplikácia, in: Aplikovaná etika a profesionálna prax, Banská Bystrica: Fakulta humanitných vied UMB.

Lee, M. D. (2008): A Review of the Teories of Corporate Social Responsibility: Its Evolutionary Path and the Road Ahead, in: International Journal of Management Reviews, 10, 1, 53-73.

Lockett, A./Moon, J./Visser, W. (2006): Corporate Social Responsibility in Management Research: Focus, Nature, Salience and Sources of Influence, in: Journal of Management Studies, 43, 1, 115-136. 
Matten, D./Crane, A. (2005): Corporate Citizenship: Towards an Extended Theoretical Conceptualization, in: Academy of Management Review, 30, 1, 166-179.

Remišová, A. (2004): Etika a ekonomika. Ekonóm : Bratislava.

Remišová, A. (2011): Etika a ekonomika. Kalligram : Bratislava.

Remišová, A. (2012): Vademecum of Business Ethics. Sprint dva: Bratislava.

Remišová, A./Búciová, Z. (2011): Methodology of determining the basis of corporate social responsibility towards employees, in: Building Capabilities for Sustainable Global Business: Balancing Corporate Success \&Social Good, Proceedings of the 12th International Conference of the Society for Global Business \& Economic Development [CD ROM], Singapore : SGBED, 2011, 651-659.

Remišová, A./Lašáková, A. (2011). Ethical leadership and effective leadership: An analysis based on the results of the GLOBE Student research in Slovakia, in: Building capabilities for sustainable global business: Balancing corporate success and social good, Volume II, Montclair : Montclair State University, 2011, 810-820.

Schwartz, M./Carroll, A. B. (2003): Corporate Social Responsibility: A Three-Domain Approach, in: Business Ethics Quarterly, 13, 4, 503-530.

Teach, E. (2005): Two Views of Virtue. CFO, Dec., 31-34.

The GoodCorporation Standard. 2007. [online] 2007 [cit. 28.2.2011] Retrived from http://www.goodcorporation.com/documents/Standard_000.pdf

Ulrich, P. (1997): Integrative Wirtschaftsethik. Grundlagen einer lebensdienlichen Ökonomie. Bern-Stuttgart-Wien : Haupt.

Ulrich, P. (2002): Der entzauberte Markt. Eine wirtschaftsethische Orientierung. FreiburgBase-Wien : Herder.

Ulrich, P. (2008): Integrative economic ethics: Foundations of a Civilized Market Economy. Cambridge : Cambridge University Press, 2008.

Wood, D. J. (2010): Measuring Corporate Social Performance: A Review, in: International Journal of Management Reviews, 12, 1, 50-84. 